\title{
Management Accounting Literature Review-Based on the Development of Management Accounting Research in 2015-2017
}

\author{
Darong Jiang \\ Management School of Jinan University, Guangzhou, China \\ Email: jdrtiffany@126.com
}

How to cite this paper: Jiang, D.R. (2019) Management Accounting Literature Review-Based on the Development of Management Accounting Research in 2015-2017. Modern Economy, 10, 2315-2334. https://doi.org/10.4236/me.2019.1012145

Received: November 11, 2019

Accepted: December 3, 2019

Published: December 6, 2019

Copyright $\odot 2019$ by author(s) and Scientific Research Publishing Inc. This work is licensed under the Creative Commons Attribution International License (CC BY 4.0).

http://creativecommons.org/licenses/by/4.0/

\begin{abstract}
This paper gives descriptive statistics on 92 articles published in four academic journals in China and two academic journals in foreign countries during 2015-2017, and systematically combs and summarizes some of these papers. Through the analysis of these literatures, it is found that the papers on management accounting have multiple themes. In recent years, with the rapid development of management accounting both in China and internationally, management accounting research has developed to a higher level. In addition, through the review of China and international management accounting literatures, we can notice the frontier direction of research and development differences between China and abroad, which can give us a general direction for future research problems and solve some practical problems faced by enterprises.
\end{abstract}

\section{Keywords}

Management Accounting, Literature Review, Value Chain, Information System, Performance Evaluation

\section{Introduction}

In recent years, as China has become the world's second largest economy, the development of the market economy has reached a new level. China's major contradictions, supply-side structural reforms, "Internet+", global economic integration, etc., have forced most of China's enterprises to transform [1]. Internal management plays an important role when the companies face many problems in the process of transformation. In October 2014, the Ministry of Finance is- 
sued the "Guiding Opinions on Comprehensively Promoting the Construction of Management Accounting System" [2]. This opinion puts forward the $4+1$ organic development model of management accounting which includes Chinese characteristics theory, guidance, talents, information and consulting services. In November 2014, CIMA issued the Global Management Accounting Principles, which proposed that management accounting is to mine, analyze, communicate and utilize financial and non-financial information related to decision-making. This not only creates value for the organization and maintains its value, but also helps and supports the organization's strategic planning, organizational implementation, and management controls to make informed decisions that promote the organization's sustainability. In June 2016, the "Basic Guidelines for Management Accounting" issued by the Ministry of Finance also clearly pointed out that the goal of management accounting is to participate in strategic planning, decision-making, control, evaluation activities and provide useful information through the use of management accounting tools to promote implementation [3]. From the relevant policy aspects of management accounting, it can be seen that the core claim is that management accounting participates in the management activities of the organization by providing useful information, and does not simply manage the control activities themselves. What is the current status and trend of management accounting research under the new economic situation? Therefore, this paper makes a simple review of the recent development of management accounting in China and abroad.

This paper selects persuasive and authoritative journals that represent the development frontier of management accounting at international or domestic levels. Chinese journals mainly include Accounting Research, Management World, Journal of Management Science, and Economic Management. Foreign journals mainly include Management Accounting Research and Accounting, Organization and Society. In order to balance the timeliness and extensiveness, this paper selects the literature published between 2015 and 2017, mainly because most of the literature reviews focus on the issues before 2014. However, in 2014, the "Guidance Opinions" of the Ministry of Finance played a significant role in the development of management accounting. There is very little literature making a descriptive statistic for the recent three years. In the process of screening articles, in addition to using keywords to filter the management accounting articles, it is mainly based on the subject of the literature to screen the qualified documents. Chinese keywords include words that are similar to "remuneration, cost, budget, management accounting, control, performance, organizational development". The search for English literature is entered as "management accounting, management control, salary, cost, performance evaluation or budget". Eventually 92 articles including 36 Chinese articles and 56 foreign literatures were gotten from 2015 to 2017.

\section{Review of Management Accounting Literature}

Contemporary accounting is divided into management accounting and financial 
accounting. There is a certain difference between the research of management accounting and the research of financial accounting. Management accounting has a wide range of research topics, including management control systems, cost accounting and management, performance evaluation and organizational development, as well as a variety of management accounting tools and information systems. Therefore, based on the characteristics of management accounting research and the literature review of Du et al. [4], this paper reviews the selected literatures according to the research topics.

\subsection{Distribution of Research Topics}

This paper refers to the methods of Du et al. and Shields to distinguish management research topics into management control systems [4] [5], cost accounting and management, decision-making methods, general issues of management accounting, external-oriented management accounting, application of information technology and other related issues. This paper relies on 92 articles from six domestic and foreign journals. The most important part of the Chinese literature comes from the management accounting part of the classification in Accounting Research. The most important sources of English literature come from Management Accounting Research, which is a journal created specifically for management accounting. The collection of this journal is more comprehensive. In addition, the literatures on management accounting are also found in other foreign journals. The division of the specific research topics is shown in Table 1 which shows the distribution of topics in Chinese and foreign literatures between 2015 and 2017.

In Table 1, Frequency-C represents the frequency of Chinese literatures and Frequency-F represents the frequency of foreign literatures.

It can be seen from Table 1 that there are 17 Chinese papers selected in 2015, 11 in 2016, 10 studies in 2017. Fourteen foreign papers are selected, 26 in 2016, and 16 in 2017. The frequency of foreign studies is greater than the frequency of Chinese papers. Since the standards for selecting literature in domestic and foreign journals are consistent, it can be known that there are still differences in research on management accounting between China and other countries. There are journals specializing in the management of accounting articles in foreign countries, and China does not have a journal that totally belongs to management accounting. From the perspective of the frequency of articles, China's management accounting research needs to be developed and needs to learn from abroad. From the total data, the frequency of articles on management accounting published every year is not much different. And the research on management accounting is in a stable state. According to the distribution of studies on various topics, the percentage of the total frequency of papers on various topics in 2015-2017 can be summed up in Tables 2-4.

From Table 1, it can be seen that the main subject are the performance evaluation system of the management control system, the performance-oriented 
Table 1. Distribution of topics during 2015-2017.

\begin{tabular}{|c|c|c|c|c|c|c|c|c|c|}
\hline \multirow{2}{*}{$\begin{array}{c}\text { Research Topics } \\
\text { year }\end{array}$} & \multicolumn{3}{|c|}{ Frequency-C } & \multicolumn{3}{|c|}{ Frequency-F } & \multicolumn{3}{|c|}{ Total Frequency } \\
\hline & 2015 & 2016 & 2017 & 2015 & 2016 & 2017 & 2015 & 2016 & 2017 \\
\hline
\end{tabular}

\section{Management control system}

1.1. Standard cost method

1.2. Operating budget

$\begin{array}{llll}1 & 1 & 1 & 1\end{array}$

1.3. Performance measurement

1.4. Transfer Pricing

1.5. Accountability Accounting

1.6. Performance Evaluation System

1.7. Performance-oriented compensation system

1.8. General issues

2. Cost accounting and

management

2.1. $\mathrm{ABC} \backslash \mathrm{ABM}$

2.2. Target cost

2.3. Environmental Cost Accounting

\begin{tabular}{|c|c|c|c|c|c|c|c|}
\hline 3 & & & 4 & 4 & 1 & 7 & 4 \\
\hline 3 & 1 & 1 & & 6 & 4 & 3 & 7 \\
\hline 2 & & 1 & 4 & 6 & 5 & 6 & 6 \\
\hline
\end{tabular}

2.4. General issues

3. Decision making method

3.1. Capital budget

3.2. The analysis of the quantity and profit

4. General issues of management accounting

5. Externally oriented management accounting

5.1. Value Chain Analysis

5.2. Strategic Management Accounting

5.3. Supply Chain Analysis

6. Management Accounting Information System

\section{Other}

$\begin{array}{lccccccccc}\text { 7.1. Value-based management } & 1 & & 1 & & & & 1 & & 1 \\ \text { 7.2. Other } & & & 1 & 1 & 1 & 2 & 1 & 1 & 3 \\ \text { Total } & 17 & 11 & \mathbf{8} & 14 & 26 & 16 & 31 & 37 & 24\end{array}$

compensation system, the general questions, and the literature on the general issues of management accounting. The frequency of subject matter in other areas is relatively small. In general, in recent years, management accounting research has focused on the general issues of management control systems, cost accounting 
Table 2. Distribution of topics in 2015.

\begin{tabular}{lc}
\hline \multicolumn{1}{c}{ Topics } & Percentage (\%) \\
\hline 1.2. Operating budget & 3 \\
1.6. Performance evaluation system & 22 \\
1.7. Performance-oriented Compensation System & 10 \\
1.8. General issues & 19 \\
2.2. Target cost & 3 \\
2.3. Environmental cost accounting & 3 \\
2.4. General issues & 9 \\
3.1. Capital budget & 6 \\
4. General Issues of management Accounting & 9 \\
5.2. Strategic management accounting & 6 \\
5.3. Supply chain analysis & 3 \\
7.1. Value-based Management & 3 \\
7.2. Other & 4 \\
\hline
\end{tabular}

Table 3. Distribution of topics in 2016.

\begin{tabular}{lc}
\multicolumn{1}{c}{ Topics } & Percentage (\%) \\
\hline 1.2. Operating budget & 3 \\
1.6. Performance evaluation system & 11 \\
1.7. Performance-oriented compensation system & 19 \\
1.8. General issues & 16 \\
2.4. General issues & 8 \\
3.1. Capital budget & 3 \\
4. General Issues of Management Accounting & 16 \\
5.1. Value chain analysis & 3 \\
5.2. Strategic management accounting & 5 \\
5.3. Supply chain analysis & 5 \\
6. Management accounting information system & 8 \\
7.2. Other & 3 \\
\hline
\end{tabular}

Table 4. Distribution of topics in 2017.

\begin{tabular}{lc}
\multicolumn{1}{c}{ Topics } & Percentage (\%) \\
\hline 1.6. Performance evaluation system & 4 \\
1.7. Performance-oriented compensation system & 21 \\
1.8. General issues & 25 \\
2.3. Environmental cost accounting & 4 \\
4. General issues of management accounting & 21 \\
5.1. Value chain analysis & 4 \\
6. Management accounting information system & 4 \\
7.1. Value-based management & 4 \\
7.2. Other & 13 \\
\hline
\end{tabular}


and management, and general issues of management accounting. But some of the literatures are about management accounting information systems. As seen from Table 2, in 2015, the literature on the performance evaluation system accounted for $22 \%$ of the total number of selected documents in the year. And the literature on the general issues of the management control system accounted for $19 \%$ of the total number in the selected year. The literature on the subject of performance-oriented compensation system accounted for $10 \%$ of the total frequency. As seen from Table 3, in 2016, the literature on the performance-oriented compensation system accounted for $19 \%$ of the total number of selected documents. And the literature on the general issues of management control systems and general issues of management accounting respectively accounted for $16 \%$ of the selected documents. The literature on the performance evaluation system accounted for $11 \%$ of selected studies in the year. The literature on the general issues of cost accounting and management and the management accounting information system accounted for $8 \%$ of the total number in 2016. From the perspective of Table 4, the literature on the general issues of the management control system accounted for $25 \%$. The literature on the performance-oriented compensation system and the general issues of management accounting accounted for $21 \%, 13 \%$ of literature on other topics, and $4 \%$ of literature on the subject of management accounting information systems.

Regardless of the distribution of the subject matter of the literature in each year, the distribution of the total literature topics for the three years from 2015 to 2017 was obtained and shown in Table 5.

Table 5. Distribution of topics between 2015 and 2017.

\begin{tabular}{lcc}
\hline \multicolumn{1}{c}{ Research Topics } & Frequency & Percentage (\%) \\
\hline 1.2. Operating budget & 2 & 2 \\
1.6. Performance evaluation system & 12 & 13 \\
1.7. Performance-oriented compensation system & 15 & 17 \\
1.8. General issues & 18 & 20 \\
2.2. Target cost & 1 & 1 \\
2.3. Environmental cost accounting & 1 & 1 \\
2.4. General issues & 6 & 7 \\
3.1. Capital budget & 3 & 3 \\
4. General issues of management accounting & 14 & 15 \\
5.1. Value chain analysis & 2 & 3 \\
5.2. Strategic management accounting & 4 & 4 \\
5.3. Supply chain analysis & 3 & 2 \\
6. Management accounting information system & 4 & 4 \\
7.1. Value-based management & 2 & 2 \\
7.2. Other & 5 & 6 \\
Total & 92 & 100 \\
\hline
\end{tabular}


From Table 5, the literature topics of management accounting research are mainly the performance evaluation system $(12,13 \%)$, the performance-oriented compensation system $(15,17 \%)$, the general problems of the management control system (18,20\%), general issues of cost accounting and management (6, $7 \%)$, general questions of management accounting (14,15\%), management accounting information system (4\%). Other topics account for $6 \%$. The contributions made by other parties cannot be ignored in the research, and the integration of various aspects promotes the development of organizational management accounting.

\subsection{Combing the Various Topics}

\subsubsection{Management Control System}

From 2015 to 2017, the performance evaluation system, the performance-oriented compensation system, and the general management accounting problem became the main research topics in the field of management accounting control systems. The scientific and reasonable performance evaluation system should fully embody the concept of organic integration of procedural rationality and result rationality. That is, it should meet the requirements of the established performance evaluation order domain and the target requirements of stakeholders for performance evaluation. As China's economic development enters a new status, this requirement is compatible with the new normal economic development characteristics, and is in line with the positioning of corporate business objectives. The performance evaluation of enterprises should increase or highlight the performance growth rate, structural adjustment and technological innovation [6]. EVA as an evaluation system for measuring performance, still plays an important role in the performance evaluation of enterprises [7]. Performance evaluation also plays an important role in the inter-organizational learning in the real world. Inter-organizational learning performance evaluation can avoid the disconnection between organizational learning ability and enterprise capacity development [8]. For the evaluation system itself, an indispensable part of the performance evaluation system is the evaluation criteria. By analyzing the interaction between the autonomous motivation and the performance evaluation system, the subjective and objective criteria contained in the evaluation system are further studied for the impact on the performance of employees with high or low autonomous motivation [9]. When the budget is used for planning and performance evaluation, it will increase the budget proposal of the subordinate during the negotiation period and his performance negotiation after the meeting. These effects tend to be greater when the superior is limited to a single budget rather than separate budgets for planning and performance evaluation, especially for subordinates' performance [10]. The development of employee participation in performance indicators is conducive to improve the quality of indicators and the subsequent impact on job performance depends on how these indicators are used. It makes sense to discuss these because managers want employees to participate in the development of operational indicators to have a positive impact 
[11]. In addition, the performance evaluation system will have an impact on the organizational logic of the organization. The logic between different organizations is different, and the institutional logic of the same organization is different in different situations [12]. The above articles all talk about the content of performance evaluation. Although the performance evaluation system is studied from different aspects, the research direction has undergone some changes. Compared with the original research enterprises, how to use the balanced scorecard has undergone some changes. Foreign literature uses more theories to support the development of the literature than the Chinese literature. Most of the Chinese use normative analysis, and often lack the use of theory.

The performance-oriented compensation system is mainly concerned with the study of managers' compensation. The salary of the manager is generally linked to the performance of the company. The payment and the level of compensation are affected by many factors, such as whether the enterprise is a family business, or if the enterprise takes social responsibility. In recent years, the form of manager's remuneration has also been studied. After 2006, the CSRC officially promulgated the Measures for the Administration of Equity Incentives for Listed Companies. The manager's remuneration is not limited to wages and bonuses. A large number of equity incentives have begun to be studied, focusing on influencing factors in the formulation of the equity incentive plan and the impact of equity incentives on performance. In addition, management incentives are studied from the aspects of self-awareness and social attribution. Corporate social responsibility and stakeholder appeals are potential important factors affecting managers' compensation incentives. Through research, it is found that corporate social responsibility does not necessarily lead to low budget constraints and managerial pay efficiency. In order to assess the compensation for state-owned enterprise managers, it is necessary to focus on the performance evaluation of corporate social responsibility [13]. The openness of the CEO has a special mechanism for the strategic inertia and organizational performance of the company [14]. The special role of relatives in family business is to influence the contractual relationship, which makes the family business different from other enterprises, and reduces the demand for the compensation contract. At the same time, the relatives themselves have achieved effective incentives and have positive effects on the company's performance [15]. In addition, excessive on-the-job consumption has an impact on the sensitivity of executive monetary compensation performance, and media supervision has mitigated this. By improving the measurement and regulation of on-the-job consumption of enterprises, it provides new ideas for improving the effectiveness of salary incentives [16]. For the formation of the management compensation system, venture capital and founders have strong governance motives and capabilities, and there are different governance demands. The existence of venture capital will increase the overall compensation level of the management of newly listed companies, expand the internal compensation gap of management, and increase the management's sal- 
ary sensitivity coefficient. In contrast, the existence of the founder leads to low management compensation and the impact of venture capital on management's internal compensation gap and compensation sensitivity coefficient [17]. Subjective performance appraisal and goal formation will affect managers' distribution of annual dividend contracts and procedural fairness. The influence of subjectivity on fairness follows the inverted $U$ shape relationship [18], which is very important for employee incentives. According to the theory of fairness, employees will improve their performance under fair recognition. The organization's relative performance evaluation (RPM) is more effective when there are opportunities for promotion at each level of the organization [19]. The design of the incentive system under unknown preferences is important for managers to make risk investment decisions based on the principle of maximizing project value [20]. Considering that employers generally provide financial rewards, they study when employers can benefit from financial rewards after employees report misconduct [21]. In addition to studying the incentives of general managers or employees, there is also an incentive design structure for white-collar workers who study middle-income levels [22]. Tournament motivation theory is very common in organizations, and tournament theory is important both in practice and in theory [23]. There are many articles on management compensation. Many of them adopt research ideas and methods in the financial field, but the research topic belongs to the research field of management accounting. The research on management compensation is more about the incentives of compensation and equity itself. It rarely talks about other aspects such as the promotion of managerial positions and the improvement of office environment. The future research direction of the compensation system is to be developed.

The general problem of the management control system is primarily the study of the management control system itself rather than its subclasses. This paper uses the idea of Mengto to define it as a general problem of management control system [2]. Such research mainly includes the following questions: 1) Introduce the application of the management control system in the enterprise. Inventory management as a basic management control means, which manager uses to monitor and reflect the behaviors and business activities occurring in the enterprise, ensuring the need for incremental information to avoid losses due to lack of supervision [24]. Otley systematically combed articles on the theory of contingency management accounting and control published between 1980 and 2014, traced the development of the literature, and critically outlined the main themes in this exploration period [25]. The method was criticized. 2) Management control has an impact on the company's performance, interpersonal relationships, internal settings, and so on. For example, studying group management control and financial company risk management, as a financial business platform within the group, the finance company needs to manage and control risks [26]. The combination of the shareholding model of the enterprise group and the management and control system will ensure that the shareholding of the enterprise 
group enters the realm of "Both form and spirit" [27]. Organizations can use the design of their control systems to influence individual costs and benefits associated with managers' rating decisions, thereby forming a manager's rating behavior [28]. Inter-organizational management control system imitation also affects its supply chain [29]. King studied the organizational performance of the interaction between ownership and professional service organization management control system design [30]. Bisbe used trust theory to study the trust between management control systems and individuals in virtual product development teams [31]. Carlsson-wal found that detailed action plans in important epidemiological events considered to ensure the structure and flexibility at the time of the occurrence are all crucial [32]. 3) The management control system itself needs innovation, and its development is also affected by many factors. For example, Bedford examines the use of management control systems under different innovation models and their impact on firm performance [33]. The control leverage framework argues that control systems must be balanced in order to scrape glass competition [34]. Through the study of Chinese state-owned enterprises, it is found that the tendency of shareholders will affect the framework of management control system practice [35]. Empirical analysis of components and systems examines the effectiveness and tactical nature of management control systems [36]. Management control systems themselves require innovation, and the interaction of ideology with formal management control systems can provide a powerful tool for business management control [37]. From the literature of the latest three years, the research on the management control system itself has been further developed. The literature in China pays attention to the conceptual analysis, and many foreign literatures are proved by empirical methods. Therefore, the literature of China has to be improved compared with the foreign literature.

\subsubsection{Cost Accounting and Management}

There was almost no research on the cost of operation $(\mathrm{ABC})$ in the selected literature between 2015 and 2017. In recent years, there have been few articles on management accounting frontiers in this area. But in practice, there are many uses of operating costs. The reason is that the $\mathrm{ABC}$ compared with the traditional cost method, which is cost-objective, accurate cost information, helps product pricing, and enhances the competitiveness of enterprises. There are one article on target cost, two articles on environmental cost accounting, and six articles on general issues of cost accounting and management. From the perspective of statistical data, the related research on cost accounting and management is less than the research literature of the previous management control system.

Target cost is the product of a combination of cost forecasting and target management methods. Setting a specific target cost will reduce the cost of the product produced by the product design team. But the effect will be different in the case of sequential and confluent new product production. Therefore, it is necessary to determine the target cost method as a useful boundary condition for the cost control method [38]. 
In the context of sustainable development, the environmental considerations embedded in the product life cycle are inseparable from the environmental management accounting to quantify, monitor and evaluate product costs, waste costs and external environmental damage. Xiao \& Xiong used the two-dimensional analysis of material flow-value flow as the starting point to discuss the calculation and analysis standards of environmental management accounting in the production and operation process [39]. Based on material flow cost (MFCA) and life cycle theory, Xiao constructed the three-dimensional model of material management-value flow-organization and its theoretical system from the three dimensions of material flow, value flow and organization, and expanded the organizational boundary of cost accounting in material circulation [40].

The general issues of cost accounting and management include the two themes of costing and cost sticking. Cost accounting includes specific cost accounting and impact factor studies. The rigorous logic of cost accounting is to realize the development of cost accounting and cost management from "computing and managing" to "arithmetic integration". Hu et al. put forward the core content of human cost accounting method, through the coupling of "person" and "object" [41]. The organic integration of cost management and cost accounting is realized at the level of human behavior. The study of cost stickiness has been relatively mature and is also a research hotspot. Lu found that the tightening monetary policy weakened the sticky cost of non-state-owned holdings and the labor cost of state-owned holding companies [42]. When the company faced a decline in business volume, the management failed to execute the liquidation option in a timely and effective manner, which made the existing resource allocation not match the current business volume change and led to the company's cost stickiness [43]. Some uncertain factors will also cause changes in the company's cost stickiness. For example, the implementation of China's "Minimum Wage Regulations" in 2004 has led to an increase in employee costs, which has an impact on the cost stickiness of Chinese enterprises [44]. Venieris et al. studied how firms' perceptions of intangible economic losses affect the stickiness of sales, general and management (SG\&A) expenses [45].

\subsubsection{Decision Making Method}

There are three articles on the topic of decision-making methods, which are similar to the results of Meng et al. [2]. Those articles are all related to the capital budget, and there is no analysis of the amount of profit. Liu et al. studied the significance construction mode in the evolution of enterprise budget management with the implementation of Shenhua Company, a Chinese local enterprise that has been implementing budget management for 16 years [46]. Amans found that how organizations with different complexities use budgets differently is shaped by multiple logics. Research budget articles rarely subdivide budgets into operating budgets, financial budgets [47]. 


\subsubsection{General Issues of Management Accounting}

This type of topic mainly includes general issues and management accounting innovation issues. The general question is about the practice of management accounting and the changes in the requirements of development at any time. The 2014 Annual Meeting of the Management Accounting Professional Committee of the China Accounting Association focused on the "Business Model Transformation and Management Accounting Research" to discuss the future direction of China's management accounting transformation and management accounting research [48]. The 2016 Annual Meeting of the Management Accounting Professional Committee of the China Accounting Association focused on the status and trends of management accounting research, management control systems, cost management, performance evaluation, risk management and organizational development, and debt problems of enterprises under the new status, and research the practice of management accounting in China [49]. Under the new economic environment, management accounting with Chinese characteristics needs innovation and development [50]. Hopper examined the contribution of Management Accounting Research (MAR) to the social critical analysis of management accounting over the past 25 years [51]. Bromwich et al. also studied and commented the meaning of the articles published since management accounting was introduced [52]. Changes in policies and institutions will also affect management accounting research. The article by Wagenhofer describes the impact of regulatory changes in the EU on management accounting research, including new opportunities for research [53]. Throughout the methods and theories of empirical accounting research used in nine accounting journals over the past 40 years, Lachmann et al. measured the diversity and effectiveness of the papers [54].

The innovation of management accounting is the requirement of scientific and technological progress. Zhang et al. reviewed the 23rd China Accounting Society Annual Meeting [1]. The meeting proposed accounting reform and innovation under the new situation, and the development of management accounting based on "Internet+". It deeply summarized the accounting practices and empirical accounting research with Chinese characteristics. The innovation of management accounting is inseparable from the innovation within the organization, including employee innovation, using social comparison and social exchange theory to analyze the role of employment identity diversity and internal person status cognition in organizational support and employee innovation behavior [55]. Although the impact of the digital revolution on management accounting and decision-making remains unclear, the fascination with the digital revolution is integrated into the historical and cultural context that is intertwined with the evolution of management accounting. It is believed that data drives the development and innovation of organizations and society. The first step in the intelligentization of decision-making has finally made management accounting a central stage in the organizational field [56]. From analysis of 
management accounting innovation adoption at the company level, management accounting innovation will be influenced by organizational culture compatibility and perception [57]. Management accounting innovation interacts with a broader social regulatory process that affects the adaptation of innovation across organizations. Chiwamit et al. took the case of EVA in Thai state-owned enterprises as an example to study this topic deeply, by addressing the problem how regulators regulate multi-interest coordination mechanisms and how regulation affects the use of these innovations across regulatory agencies [58].

\subsubsection{Externally Oriented Management Accounting}

Externally oriented management accounting includes three topics: value chain analysis, strategic management accounting, and supply chain management. Articles on the supply chain are often closely related to other disciplines. This paper selects articles that are closely related to management accounting. Adopting the vertical integration strategy will significantly affect the company's profitability. In different countries, the performance should be different. Enterprises should choose a vertical integration strategy that suits their own industry characteristics and continuously optimize the value chain. The government should encourage efficient integration through industrial policy levers, especially supporting technological innovation to improve the performance of industrial value chain [59]. Sha et al. analyzed the importance of different management accounting tools in each node of the value chain, and has certain guiding significance for guiding enterprises to rationally select and apply management accounting work and improve the application efficiency of management accounting tools [60].

The study of the relationship between strategy and corporate performance has always been an important research issue in the field of corporate management. The improvement of corporate performance lags behind the implementation of competitive strategy. The performance of competitive strategy is lagging and persistent [61]. Enterprises adopting different competitive strategies will exhibit different cost behaviors, that is, corporate strategy has impact on cost stickiness [62]. Lapsley examined the relationship between accounting and popular culture research from a strategic perspective and further understand how to apply strategic management accounting to popular culture [63].

Supply chain cost allocation is the supply chain costing kernel and supply chain cost management information expression. It is different from the general enterprise cost allocation. It is the goal of pursuing the optimal cost of the entire supply chain to replace the cost of the single enterprise in the chain and improve the competitive advantage of overall supply chain. Chen et al. studied the contingency of supply chain cost allocation [64]. Purchasing in the supply chain is one of the key factors affecting the survival and development of the company. The correct order allocation is the key to the successful implementation of procurement management. The risk of supply disruption is a potential threat. It will use the vulnerability of the supply chain system to damage the supply chain sys- 
tem, causing damage and loss to the upstream and downstream enterprises and the entire supply chain. Therefore, the company should choose the best solution for order allocation [65].

\subsubsection{Management Accounting Information System}

The management accounting information system mainly meets the internal management needs of the enterprise and provides decision support for the enterprise strategy, tactics and daily operation management. In the context of networked operation, Zhu et al. studied the value creation mechanism of information system governance under the background of enterprise network application, and proposed the concept and composition of information system governance among enterprises [66]. Sun examined the situation in China [67]. The impact of information system integration on the fairness of the budget process and the impact of budgetary procedures on corporate performance are extremely critical. Cardinaels provided experimental evidence on how the interaction between the company's earnings and its information systems affects the extent to which managents report honestly in capital budgeting tasks [68]. In recent years, with the rapid development of artificial intelligence and big data, the management accounting information system is also being upgraded to further improve the information system.

\subsubsection{Other}

Such research includes literatures ( 5 articles) outside the above research categories, such as value-based management, management accounting applied to popular culture, and art investment. Zhu et al. defined the functional boundaries of management accounting in combination with the targets, objects and essence of management accounting, and abstracted the value creation activities of enterprises into the value creation system of CVA and EVA integration, showing the basic value logic of enterprise value creation [69]. Enterprises combine management accounting with the use of economic, social, and technical frameworks to jointly develop products and increase the flexibility and reliability of production and management activities [70]. Management accounting information plays an important role in the enterprise and is of great significance for assessing the peculiar events in the business. At present, the development of the mass culture industry cannot be underestimated, and its economic achievements account for a large proportion of China's GDP. The use of performance ratings and narrative information in management accounting to guide the choice of film audiences is another innovation in practice. Based on web-based and interview-based research, Bialecki et al. explore how the management accounting tools embedded in IMDb play a role in shaping diverse social outcomes related to popular culture (in this case, unpredictable change movies) and further explore how these tools became an integral part of the core functions of innovative social phenomena (such as IMDb) [71]. In the management accounting literature, there is little attention in the process of popular culture production. Al- 
though the broader organizational literature emphasizes the contradictory nature of cultural industry management, considering the common needs of art and business, there are few reports on how to manage creative labor. From research of 82-day television series produced by ethnographic perspective, Maier found how the micro-processes of computational practice are interwoven into the different disciplines that make up the project team [72]. The development of knowledge, practice and tools is a necessary condition for viewing art as an asset class. Crucially, the cognitive culture approach highlights deepening knowledge, resources, and expertise, and their development has gone through experiments, failures, and testing of negative knowledge. Coslor examined the development of the art investment sector through a cognitive culture perspective, demonstrating how the knowledge community supports the legitimacy of new products for performance evaluation before purchase [73].

\section{Summary}

Through the summary of the main subject literatures of management accounting between 2015 and 2017, it is found that the literature on management accounting research in China has further development after the promulgation of Guiding Opinions, Global Management Accounting Principles and Basic Accounting Guidelines. The literature that was originally limited to research cost accounting and management tilted toward performance evaluation and compensation management. Foreign literature has more papers on management control itself, and proves the impact of management control system on all aspects of the enterprise from an empirical perspective. China's literature mainly uses economic theory and financial theory. The papers combined with psychology, applied sociology are less. Implementing a series of policy opinions needs to combine China's social and economic conditions and cultural background. The object selects the appropriate theory and even constructs the management accounting theory based on the Chinese background, and improves the theoretical, academic and international nature of management accounting research. The management accounting professional committee meeting held in the latest two years has developed the management accounting under the new normal of economic development. The direction has been discussed in depth. And the goal is to form a "theory system of management accounting with Chinese characteristics". China's management accounting research has a long way to go. However, from the perspective of domestic and international, with the integration of the global economy, China has become the world's second largest economy. The management accounting practice of Chinese enterprises has attracted the attention of scholars in China and abroad. For example, articles based on Chinese state-owned enterprises have also been published in top international journals. The international management accounting research has gradually developed. The original management accounting research mainly focused on the research of entity enterprises. Recently, the research on the management accounting appli- 
cation of mass culture enterprises has already emerged, which is of great significance to the current cultural development and consumption. In addition, management accounting innovation has begun to emerge in the study of management accounting. Through simple combing, it can be found that management accounting research is moving in a better direction.

\section{Conflicts of Interest}

The author declares no conflicts of interest regarding the publication of this paper.

\section{References}

[1] Zhang, H., Zhang, Q.L. and Ma, J.W. (2017) Accounting Reform and Innovation in the New Situation-A Summary of the 23rd Annual Academic Meeting of the Higher Institute of Engineering of China Accounting Society. Accounting Research, 2, 93-95.

[2] Meng, Y., Sun, J., Lu, W. and Liu, J.Y. (2014) Review and Outlook of China's Management Accounting Research. Accounting Research, 9, 3-12.

[3] Ao, X.B., Li, X.H. and Zhao, Y.N. (2017) Innovation and Integration of Management Accounting Tools-Based on the Case of Xinhua Group. Economic Management, No. 10, 11.

[4] Du, R.R., Xiao, Z.Z. and Zhou, Q.W. (2009) Review of China's Management Accounting Research. Accounting Research, 9, 72-80.

[5] Shields, M.D. (1997) Research in Management Accounting by North Americans in the 1990s. Journal of Management Accounting Research, 9, 3-62.

[6] Zhang, R. (2015) On the Enterprise Performance Evaluation of the Organic Integration of Procedural Rationality and Result Rationality under the New Normal. Accounting Research, 10, 89-92.

[7] Tang, G.L. and Dai, T.Q. (2015) Theoretical Explanation of the Implementation Effect of EVA Evaluation System in Central Enterprises. Accounting Research, 9, 35-43.

[8] Dai, W. and Zhi, X.Q. (2015) Can the Enterprise "Clearly Distinguish" the Learning Effectiveness in the Cooperation between Organizations?-The Perspective of Performance Evaluation. Accounting Research, 12, 45-52.

[9] Kunz, J. (2015) Objectivity and Subjectivity in Performance Evaluation and Autonomous Motivation: An Exploratory Study. Management Accounting Research, 27, 27-46. https://doi.org/10.1016/j.mar.2015.01.003

[10] Arnold, M.C. and Gillenkirch, R.M. (2015) Using Negotiated Budgets for Planning and Performance Evaluation: An Experimental Study. Accounting, Organizations and Society, 43, 1-16. https://doi.org/10.1016/j.aos.2015.02.002

[11] Groen, B.A.C., Wouters, M.J.F. and Wilderom, C.P.M. (2017) Employee Participation, Performance Metrics, and Job Performance: A Survey Study Based on Self-Determination Theory. Management Accounting Research, 36, 51-66. https://doi.org/10.1016/j.mar.2016.10.001

[12] Carlsson-Wall, M., Kraus, K. and Messner, M. (2016) Performance Measurement Systems and the Enactment of Different Institutional Logics: Insights from a Football Organization. Management Accounting Research, 32, 45-61. https://doi.org/10.1016/j.mar.2016.01.006 
[13] Wang, X., Li, Y.L. and Li, F.S. (2015) Research on the Effectiveness of Corporate Social Responsibility and Managers' Salary Incentives-Strategic Motivation Is an Excuse for Excusing? Accounting Research, 10, 51-58.

[14] Lian, Y.L. and He, X.G. (2015) CEO Openness, Strategic Inertia and Organizational Performance: An Empirical Analysis Based on Chinese Listed Companies. Journal of Management Science, 18, 1-19.

[15] Zhao, Y.Y. and Lu, C.J. (2015) Affinity or Benefit?-The Influence of Family Business Relationship on Compensation Contract. Accounting Research, 8, 32-40.

[16] Geng, Y.J. and Wang, M.X. (2016) Excessive On-the-Job Consumption, Sensitivity of Monetary Compensation Performance and Media Supervision-Based on Chinese Listed Companies Empirical Evidence. Accounting Research, 9, 55-61.

[17] Chen, W., Zhang, Y. and Wu, X.H. (2017) Venture Capital, Founder and Executive Compensation-Multilateral Agent Perspective. Management Science Newspaper, 20, 78-88.

[18] Voußem, L., Kramer, S. and Schäffer, U. (2016) Fairness Perceptions of Annual Bonus Payments: The Effects of Subjective Performance Measures and the Achievement of Bonus Targets. Management Accounting Research, 30, 32-46. https://doi.org/10.1016/j.mar.2015.10.001

[19] Demeré, B.W., Krishnan, R., Sedatole, K.L. and Woods, A. (2016) Do the Incentive Effects of Relative Performance Measurement Vary with the ex Ante Probability of Promotion? Management Accounting Research, 30, 18-31. https://doi.org/10.1016/j.mar.2015.09.002

[20] Ortner, J., Velthuis, L. and Wollscheid, D. (2017) Incentive Systems for Risky Investment Decision under Unknown Preferences. Management Accounting Research, 36, 43-50. https://doi.org/10.1016/j.mar.2016.09.001

[21] Stikeleather, B.R. (2016) When Do Employers Benefit from Offering Workers a Financial Reward for Reporting Internal Misconduct? Accounting, Organizations and Society, 52, 1-14. https://doi.org/10.1016/j.aos.2016.06.001

[22] Baik, B., Evans III, J.H., Kim, K. and Yanadori, Y. (2016) White Collar Incentives. Accounting, Organizations and Society, 53, 34-49.

https://doi.org/10.1016/j.aos.2015.11.006

[23] Kelly, K. and Presslee, A. (2017) Tournament Group Identity and Performance: The Moderating Effect of Winner Proportion. Accounting, Organizations and Society, 56, 21-34. https://doi.org/10.1016/j.aos.2016.12.001

[24] Tian, G.L., Zhao, H.X. and Li, J.Y. (2015) Exploring the Embedded Management Accounting System of Inventory Management. Accounting Research, 4, 55-61.

[25] Otley, D. (2016) The Contingency Theory of Management Accounting and Control: 1980-2014. Management Accounting Research, 31, 45-62. https://doi.org/10.1016/j.mar.2016.02.001

[26] Yuan, L. and Zhang, W.H. (2015) Group Management Control and Financial Company Risk Management-Based on Multiple Cases of 10 Enterprise Groups Analysis. Accounting Research, 5, 35-41.

[27] Sun, N. and Wang, B.P. (2017) Research on Shareholding Model, Management and Control System and Performance of Enterprise Group-Based on 210 Enterprises Group's Empirical Data. Accounting Research, 4, 52-58.

[28] Bol, J.C., Kramer, S. and Maas, V.S. (2016) How Control System Design Affects Performance Evaluation Compression: The Role of Information Accuracy and Outcome Transparency. Accounting, Organizations and Society, 51, 64-73. 
https://doi.org/10.1016/j.aos.2016.01.001

[29] Reusen, E., Roodhooft, F., Stouthuysen, K., Van den Abbeele, A.G. and Slabbinck, H. (2016) Management Control System Imitation in Supply Chains. Available at SSRN 2833280.

[30] King, R. and Clarkson, P. (2015) Management Control System Design, Ownership, and Performance in Professional Service Organisations. Accounting, Organizations and Society, 45, 24-39. https://doi.org/10.1016/j.aos.2015.06.002

[31] Bisbe, J. and Sivabalan, P. (2017) Management Control and Trust in Virtual Settings: A Case Study of a Virtual New Product Development Team. Management Accounting Research, 37, 12-29. https://doi.org/10.1016/j.mar.2017.02.001

[32] Carlsson-Wall, M., Kraus, K. and Karlsson, L. (2017) Management Control in Pulsating Organisations-A Multiple Case Study of Popular Culture Events. Management Accounting Research, 35, 20-34. https://doi.org/10.1016/j.mar.2016.01.002

[33] Bedford, D.S. (2015) Management Control Systems across Different Modes of Innovation: Implications for Firm Performance. Management Accounting Research, 28, 12-30. https://doi.org/10.1016/j.mar.2015.04.003

[34] Kruis, A.M., Speklé, R.F. and Widener, S.K. (2016) The Levers of Control Framework: An Exploratory Analysis of Balance. Management Accounting Research, 32, 27-44. https://doi.org/10.1016/j.mar.2015.12.002

[35] Yang, C.L. and Modell, S. (2015) Shareholder Orientation and the Framing of Management Control Practices: A Field Study in a Chinese State-Owned Enterprise. Accounting, Organizations and Society, 45, 1-23. https://doi.org/10.1016/j.aos.2015.06.001

[36] Bedford, D.S., Malmi, T. and Sandelin, M. (2016) Management Control Effectiveness and Strategy: An Empirical Analysis of Packages and Systems. Accounting, Organizations and Society, 51, 12-28. https://doi.org/10.1016/j.aos.2016.04.002

[37] Kraus, K., Kennergren, C. and von Unge, A. (2017) The Interplay between Ideological Control and Formal Management Control Systems: A Case Study of a Non-Governmental Organization. Accounting, Organizations and Society, 63, 42-59. https://doi.org/10.1016/j.aos.2016.02.001

[38] Gopalakrishnan, M., Libby, T., Samuels, J.A. and Swenson, D. (2015) The Effect of Cost Goal Specificity and New Product Development Process on Cost Reduction Performance. Accounting, Organizations and Society, 42, 1-11. https://doi.org/10.1016/j.aos.2015.01.003

[39] Xiao, X. and Xiong, F. (2015) PDCA Cycle Study of Environmental Management Accounting. Accounting Research, 4, 62-69.

[40] Xiao, X., Zeng, H.X. and Li, S.H. (2017) Three-Dimensional Model Study of Material Management Accounting "Material Flow-Value Flow-Organization". Accounting Research, 1, 15-22.

[41] Hu, C.H. and Zhang, J.C. (2015) Human Cost Kernel Algorithm Based on Coupling Degree of Human and Object. Accounting Research, 11, 20-26.

[42] Lu, R. and Chen, S.L. (2015) Monetary Policy Fluctuation and Corporate Labor Cost Stickiness. Accounting Research, 12, 53-58.

[43] Xiao, T.S., Yan, Q.L. and Chen, X.Y. (2016) Industry Competition and Corporate Cost Stickiness: Based on Real Option Perspectives. Management Science Newspaper, 19, 48-63.

[44] Jiang, W., Yao, W.B. and Hu, Y.M. (2016) Implementation of the Minimum Wage Regulations and Enterprise Cost Stickiness. Accounting Research, 10, 56-62. 
[45] Venieris, G., Naoum, V.C. and Vlismas, O. (2015) Organisation Capital and Sticky Behaviour of Selling, General and Administrative Expenses. Management Accounting Research, 26, 54-82. https://doi.org/10.1016/j.mar.2014.10.003

[46] Liu, L.B., Han, X.D. and Yang, F. (2015) Evolution and Significance Construction of Group Enterprise Budget Management-Based on Shenhua Group Longitudinal Case Study from 1998 to 2014. Accounting Research, 7, 42-48.

[47] Amans, P., Mazars-Chapelon, A. and Villesèque-Dubus, F. (2015) Budgeting in Institutional Complexity: The Case of Performing Arts Organizations. Management Accounting Research, 27, 47-66. https://doi.org/10.1016/j.mar.2015.03.001

[48] Sun, M.Z. and Xu, K. (2015) Business Model Transformation and Management Accounting Research-Management Accounting Professional Committee of China Accounting Association Summary of the 2014 Annual Meeting. Accounting Research, 1, 90-92.

[49] Huang, H., Pan, F. and Liu, H.M. (2017) Practice of Management Accounting in Chinese Enterprises-Management Accounting Professional Committee Member of China Accounting Association Summary of the 2016 Academic Annual Meeting. Accounting Research, 3, 90-93.

[50] Guan, R.Z. and Nan, X.H. (2016) Innovation and Development of Management Accounting with Chinese Characteristics under the New Normal-Management Association of China Accounting Association Summary of the 2016 Special Symposium of the Professional Committee. Accounting Research, 11, 92-94.

[51] Hopper, T. and Bui, B. (2016) Has Management Accounting Research Been Critical? Management Accounting Research, 31, 10-30.

https://doi.org/10.1016/j.mar.2015.08.001

[52] Bromwich, M. and Scapens, R.W. (2016) Management Accounting Research: 25 Years on. Management Accounting Research, 31, 1-9. https://doi.org/10.1016/j.mar.2016.03.002

[53] Wagenhofer, A. (2016) Exploiting Regulatory Changes for Research in Management Accounting. Management Accounting Research, 31, 112-117. https://doi.org/10.1016/j.mar.2015.08.002

[54] Lachmann, M., Trapp, I. and Trapp, R. (2017) Diversity and Validity in Positivist Management Accounting Research-A Longitudinal Perspective over Four Decades. Management Accounting Research, 34, 42-58. https://doi.org/10.1016/j.mar.2016.07.002

[55] Liu, Z.Q., Deng, C.J., Liao, J.Q. and Long, L.R. (2015) Organizational Support, Status Cognition and Employee Innovation: Employment Diversity Perspective. Journal of Management Science, 18, 80-94.

[56] Quattrone, P. (2016) Management Accounting Goes Digital: Will the Move Make It Wiser? Management Accounting Research, 31, 118-122. https://doi.org/10.1016/j.mar.2016.01.003

[57] Ax, C. and Greve, J. (2017) Adoption of Management Accounting Innovations: Organizational Culture Compatibility and Perceived Outcomes. Management Accounting Research, 34, 59-74. https://doi.org/10.1016/j.mar.2016.07.007

[58] Chiwamit, P., Modell, S. and Scapens, R.W. (2017) Regulation and Adaptation of Management Accounting Innovations: The Case of Economic Value Added in Thai State-Owned Enterprises. Management Accounting Research, 37, 30-48. https://doi.org/10.1016/j.mar.2017.03.001

[59] Wang, B. and Wang, L.J. (2016) Vertical Integration, Industry Heterogeneity and 
Corporate Profitability-Based on the Listing of China, Canada and Australia Comparative Analysis of Divisions. Accounting Research, 4, 70-76.

[60] Sha, X.J., Wang, M., Zhong, F., Ye, X.J. and Wang, Y.Z. (2017) Research on the Importance of Management Accounting Tools from the Perspective of Value Chain-Based on the Questionnaire and Analysis of Chinese Enterprises. Accounting Research, 4, 66-72.

[61] Lei, H., Wang, Y.N., Nie, S.S. and Ouyang, L.P. (2015) Research on Time Delay Effect of Competitive Strategy Performance Based on Financial Performance Composite Index. Accounting Research, 5, 64-71.

[62] Zhou, B., Zhong, T.Y., Xu, H. and Ren, Z.L. (2016) Corporate Strategy, Managerial Expectation and Cost Stickiness-Based on Chinese Listed Companies Empirical Evidence. Accounting Research, 7, 58-65.

[63] Lapsley, I. and Rekers, J.V. (2017) The Relevance of Strategic Management Accounting to Popular Culture: The World of West End Musical. Management Accounting Research, 35, 47-55. https://doi.org/10.1016/j.mar.2017.01.001

[64] Chen, L.H., Zu, Y.F. and Han, J. (2016) Research on the Contingency Structure of Supply Chain Cost Allocation. Accounting Research, 10, 50-55.

[65] Pan, W. (2015) Fuzzy Multi-Objective Order Allocation Model Based on Supply Interruption Risk. Journal of Management Science, 18, 45-51.

[66] Zhu, S.T., Zhong, W.J. and Mei, W. (2016) Research on Value Creation of Information System Governance between Enterprises. Management Science Newspaper, 19, 60-77.

[67] Sun, J., Wang, B.Q. and Yuan, R.L. (2017) Information System Integration, Budget Process Fairness and Corporate Performance: A State-Owned Enterprise Industry Research. Management World, 5, 131-143.

[68] Cardinaels, E. (2016) Earnings Benchmarks, Information Systems, and Their Impact on the Degree of Honesty in Managerial Reporting. Accounting, Organizations and Society, 52, 50-62. https://doi.org/10.1016/j.aos.2015.09.002

[69] Zhu, B. and Gan, S.D. (2015) Market Competition, Business Strategy and Performance Evaluation Indicator Selection. Accounting Research, 2, 51-57.

[70] van der Meer-Kooistra, J. and Scapens, R.W. (2015) Governing Product Co-Development Projects: The Role of Minimal Structures. Management Accounting Research, 28, 68-91. https://doi.org/10.1016/j.mar.2015.05.001

[71] Bialecki, M., O'Leary, S. and Smith, D. (2017) Judgement Devices and the Evaluation of Singularities: The Use of Performance Ratings and Narrative Information to Guide Film Viewer Choice. Management Accounting Research, 35, 56-65. https://doi.org/10.1016/j.mar.2016.01.005

[72] Maier, E.R. (2017) The Budget in the Aesthetic: The Role of Calculative Practice in the Production of Popular Culture. Management Accounting Research, 35, 83-98. https://doi.org/10.1016/j.mar.2016.03.001

[73] Coslor, E. and Spaenjers, C. (2016) Organizational and Epistemic Change: The Growth of the Art Investment Field. Accounting, Organizations and Society, 55, 48-62. https://doi.org/10.1016/j.aos.2016.09.003 